Волотівський П. Б., канд. військ. наук, ст. наук. співроб. ${ }^{1}$ (ORCID 0000-0002-1479-883X);

Левчук О. В., канд. екон. наук, доцент ${ }^{1}$ (ORCID 0000-0002-2827-2134); Хвостіченко В. М. ${ }^{2}$ (ORCID 0000-0003-3518-2273)

1 - Центр воєнно-стратегічних досліджень Національного університету оборони України імені Івана Черняховського, Київ;

2 - Центральний науково-дослідний інститут озброєння і військової техніки, Київ

\title{
Воснно-економічні аспекти бойових дій в прилеглих до чорноморського узбережжя України районах моря
}

Резюме. У статті розглядаються можливі напрями зниження вартості вирішення завдань оборони держави з морського напрямку за умови різних варіантів побудови оборони морського узбережжя та способів застосування військ (сил), що відповідають критерію - висока ефективність за прийнятних витратах та втратах.

Ключові слова: оборона морського узбережжя; економічна ефективність як критерій вирішення бойових завдань на морі; ресурсні можливості держави; воєнно-економічні дослідження; побудова оборони держави з моря; вирішення завдань бойових дій на морі спільними зусиллями видів збройних сил; ближня зона оборони; дальня зона оборони; вартість експлуатації зразка озброєння та військової техніки.

Постановка проблеми. Україна на сьогодні має обмежені економічні можливості щодо будівництва й розвитку власних Військово-Морських Сил Збройних Сил України. За таких обставин важливо забезпечити обороноздатність держави 3 морського напрямку 3 найменшими витратами ресурсів. Отже, одним 3 пріоритетних напрямів наукових досліджень $є$ пошук шляхів вирішення завдань оборони держави 3 моря 3 урахуванням наявних можливостей та ресурсів при забезпеченні заданої ефективності вирішення завдань 3 мінімальними витратами фінансових та інших ресурсів.

Аналіз останніх досліджень i публікацій. Дослідження 3 цієї проблематики в Україні в останні роки не здійснювались. Деякою мірою питання вартості вирішення завдань оборони держави 3 моря порушувались під час проведення оборонних оглядів. Однак повноцінні дослідження щодо пошуку варіантів складу сил і засобів для вирішення завдань на морі спільними зусиллями видів Збройних Сил України (BMC, ПС, СВ) із заданою ефективністю за мінімальною їх вартістю та матеріальними витратами не проводились.

Метою статті с узагальнення основних напрямів зниження вартості вирішення основних завдань оборони морського узбережжя України в Азовському та Чорному морях за допомогою вибору раціонального способу побудови оборони, пошуку оптимальних варіантів складу сил і засобів для вирішення завдань на морі спільними зусиллями видів Збройних Сил України при забезпеченні заданої ефективності вирішення завдань 3 мінімальними витратами фінансових та інших ресурсів.

Виклад основного матеріалу. Забезпечення національної безпеки і оборони України, боєздатності та оснащеності Збройних Сил України (ЗС України) 3 небувалою гостротою ставить перед державою проблему раціонального використання ресурсів, насамперед, у військовій сфері [1].

Зусилля, спрямовані на зниження тягаря військових витрат, мають бути беззаперечним пріоритетом у всіх сферах діяльності. Для 3С України до числа основних керівних принципів їх розвитку відноситься принцип забезпечення оборонної достатності 3 урахуванням фінансово-економічних можливостей держави $[2,3]$. Передусім ця вимога стосується Військово-Морських Сил (ВМС) ЗС України, оскільки флот будується довго, коштує дорого, експлуатується десятиліттями й споживає ресурси, навіть знаходячись біля пірсу.

ВМС унаслідок кримських подій 2014 року втратили 51 корабель. У їхньому складі залишилося 16 бойових кораблів і катерів, що можуть виконувати певні (обмежені) бойові завдання [3].

Усе це вимагає від керівництва ЗС України, зокрема від керівництва ВМС, пошуку нових способів організації оборони приморсько-прибережної зони та застосування 
військ (сил), які грунтуються на євроатлантичному досвіді та відповідають єдиному критерію - висока ефективність за прийнятних витратах [2].

Аналіз складу Чорноморського флоту та Каспійської воєнної флотилії Російської Федерації дає змогу дійти висновку, що для ведення воєнних дій у закритих акваторіях Чорного та Азовського морів агресор (РФ) може використати значне угруповання збройних сил, основу якого складатимуть угруповання ВМФ. До складу цього угруповання можуть залучатись надводні кораблі та дизельні підводні човни 3 крилатими ракетами морського базування, корабельні ударні групи ракетних кораблів і катерів, берегові ракетні частини, морська i тактична авіація, 3'єднання протимінних кораблів, угруповання сил 3 оборони районів базування. Зазначене угруповання має у своєму складі значні амфібійні сили та з'єднання морської піхоти [3].

3 урахуванням воєнно-географічних чинників (розміри зони бойових дій на морі, володіння противником ключовими позиціями в морській зоні, мілководність Азовського моря та північно-західних районів Чорного моря, сезонність використання окремих прибережних районів морів, лиманів, судноплавних річок з причини їх замерзання) оборона морського узбережжя України визначеними угрупованнями 3С України в Азовському та Чорному морях мас будуватись, насамперед, як протиповітряна та протидесантна. Ї̈̈ основний зміст полягає у використанні всіх вогневих засобів для знищення авіації, крилатих ракет морського базування в повітрі та морських десантів під час їх входження в оборонну зону та проривання в райони висадки.

Для ВMC це практично означає, що потрібно бути у постійній готовності до участі у відбитті повітряних ударів противника, висадки його морських десантів і диверсійнорозвідувальних груп. Для цього потрібно мати такий склад сил (спроможностей), щоб спільно 3 іншими видами 3С України відбити повітряні удари противника, зірвати висадку морських десантів і, крім того, забезпечити оборону районів базування, прибережних морських комунікацій, важливих об'єктів на узбережжі, охорону об'єктів у виключній (морській) економічній зоні України, не допустити блокади морського узбережжя, військово-морських баз, портів тощо.

Отже, Україні вже сьогодні потрібна така програма розвитку флоту, реалізація якої за мінімальних фінансових затратах дала змогу б створити ВМС, здатні спільно 3 іншими видами 3С України захистити суверенітет та територіальну цілісність держави 3 морських напрямків [4, 5, 9].

Вартісні аспекти вирішення військами (силами) завдань у бойових діях набувають зараз особливої актуальності. Це обумовлює необхідність врахування економічної ефективності як критерію виконання бойових завдань, вимагає підвищення економічної підготовки офіцерів, уміння обчислювати вартість рішень на бій (операцію), що приймаються, й оцінювати їх результати як 3 позицій бойової, так і економічної ефективності [6].

Нині головна загроза для ВМС - це обвальне зменшення кількості корабельних сил та боєздатних зразків озброєння, військової та спеціальної техніки (ОВТ), насамперед високотехнологічних [7]. За нормативними термінами експлуатації корпусів, систем та механізмів на сьогодні підлягають списанню близько 70 \% бойових кораблів і катерів, що є у складі ВМС. Терміни експлуатації багатьох зразків зброї закінчились, 60 \% артилерійських боєприпасів потребують фізико-хімічних випробувань. Усі типи тралів за своїм технічним станом фактично не придатні до використання. Не краща обстановка зі станом інших видів озброєння та техніки. Відсутність у держави можливостей щодо укомплектування та оснащення ВМС потрібною кількістю кораблів, авіації, зброї вимагає пошуку шляхів вирішення завдань оборони держави 3 морського напрямку 3 урахуванням наявних можливостей та ресурсів.

Результати

воєнно-економічних досліджень, які проводились Міністерством оборони України впродовж останніх років свідчать, що основними напрямами зниження вартості вирішення завдань на морі є:

удосконалення структури побудови оборони держави 3 моря на основі визначених та обгрунтованих реальних завдань ВМС у рамках загальних завдань оперативного угруповання військ (сил), призначеного для оборони держави 3 морського напрямку;

компенсація слабких тактичних властивостей одних видів (родів) військ (сил) завдяки сильним властивостям інших;

зосередження основних зусиль щодо відбиття ударів з моря і повітря у ближній зоні, де забезпечується надійна ППО корабельних сил під час дій у морі; 
вибір чисельного складу нарядів сил для виконання визначених завдань із заданою ефективністю за мінімальних затратах;

застосування

радіолокаційних повітряної та надводної обстановки, стаціонарних гідроакустичних та електронних засобів виявлення підводних човнів, підводних засобів доставки диверсійнорозвідувальних груп;

застосування оборонних мінних загороджень;

запобігання втратам, впровадження систем забезпечення захисту та живучості кораблів;

прийняття як пріоритетного напряму розвитку ВМС - розвитку сил i засобів прибережної зони дії, системи освітлення i розвідки в морській зоні.

Головним висновком, який випливає 3 результатів проведених досліджень, є необхідність вирішення усієї сукупності завдань бойових дій щодо оборони держави 3 моря спільними зусиллями створеного угруповання сил оборони. До зазначеного угруповання мають входити з'єднання, частини, формування усіх видів і родів військ (сил) 3С України, інших військових формувань, правоохоронних і розвідувальних органів, органів спеціального призначення: з'єднання військ ППО, з'єднання винищувальної, бомбардувальної та штурмової авіації Повітряних Сил; підрозділи системи висвітлення морської обстановки; ударні групи ракетних катерів; з'єднання протичовнових кораблів; берегові ракетні частини; частини берегової артилерії; сили і засоби протимінних та мінно-загороджувальних дій; з’єднання та частини оперативно-тактичного угруповання сухопутних військ, які виділені для протидесантної оборони узбережжя; частини спеціальних операцій; угруповання спеціальних військ, озброєння та тилу, підрозділи інших військових формувань: правоохоронних i розвідувальних органів, органів спеціального призначення, територіальної оборони.

Підтвердженням доцільності врахування зазначених рекомендацій $є$ окремі судження i приклади, які грунтуються на нормативних нарядах сил для вирішення тих чи інших завдань, та орієнтовних вартостях кораблів i літаків (табл. 1).

Таблиця 1

Вартість основних типів кораблів, літаків (у цінах 1996 року)

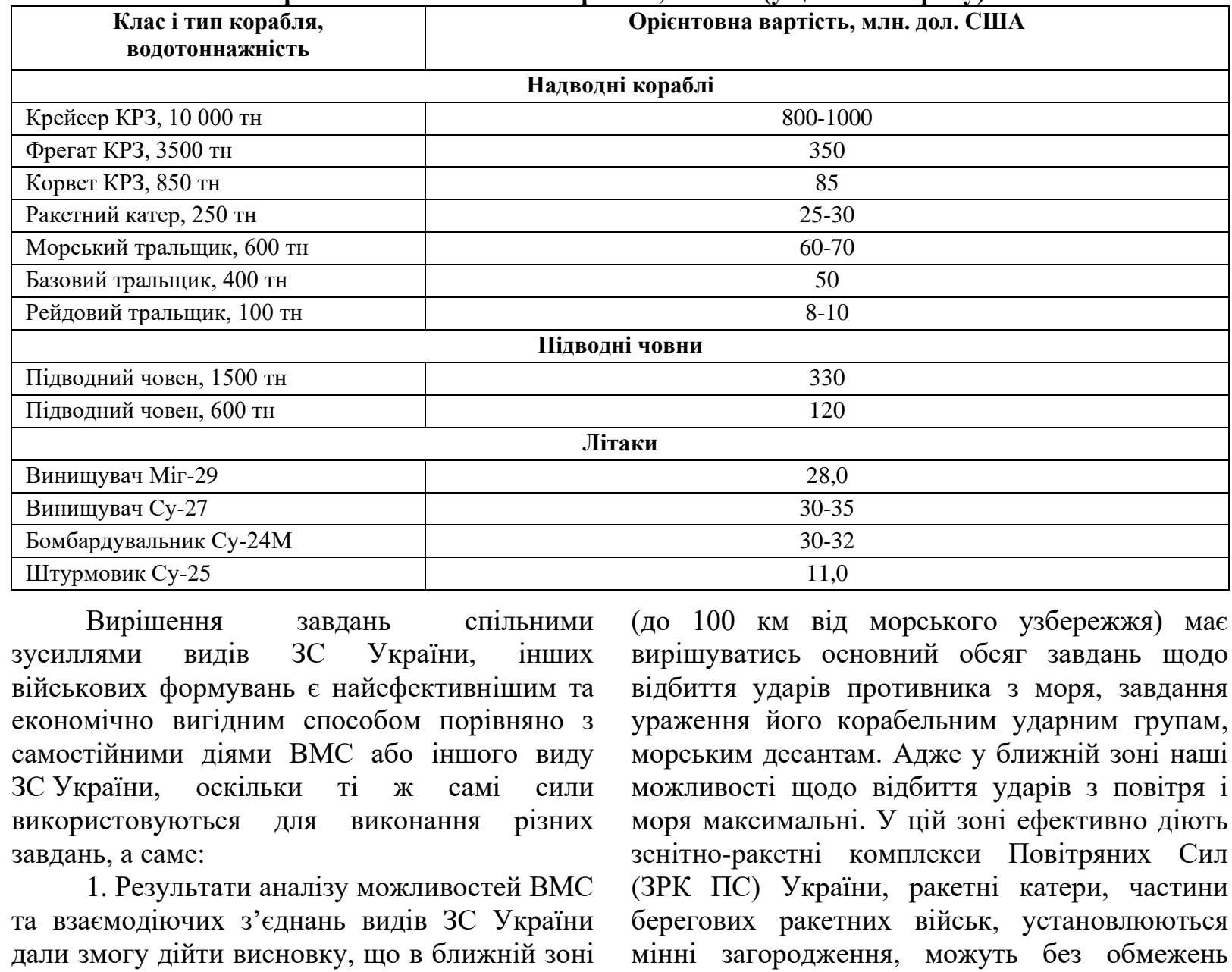


застосовуватись тактична авіація та бойові вертольоти. Зосередження зусиль на відбитті ударів противника у ближній зоні зменшить ризик втрат кораблів та авіації ВМС. У цій зоні вони надійно прикриваються на відстань до 50 км ЗРК ПС, винищувальною авіацією. У разі переміщення маневрених протичовнових сил, які можуть складатися 3 двох корабельнопошукових ударних груп (КПУГ 6-8 кораблів), 5-7 протичовнових літаків, 12-14 протичовнових вертольотів, 3 дальньої у ближню зону можна запобігти втратам до $20 \%$ зазначених сил. Це 1-2 кораблі, 1 протичовновий літак, 2-3 протичовнових вертольоти.

Звертаємо увагу на те, що сили та засоби, призначені для дій у ближній зоні, мають значно меншу вартість порівняно 3 силами і засобами для дій у морській зоні плавання (дальній зоні). На теперішній час будівництво військових кораблів стає більш вартісним. Якщо $30-40$ років тому тонна водотоннажності корабля коштувала приблизно 100 тис. доларів США, то на сьогодні ії вартість зросла до 150 тис. доларів США [3].

$$
\text { 2. Різниця вартості нарядів }
$$

протичовнових кораблів і ракетних кораблів (катерів) для дій у ближній і дальній зонах становить приблизно 1360-1760 млн доларів США і 850-760 млн доларів США відповідно (табл. 2). Значний розмір такої розбіжності підкреслює необхідність визначення пріоритетів у розвитку ВМС на найближчу перспективу.

Таблиця 2

Порівняльна вартість нарядів сил для вирішення завдань ПКО та ПЧО в ближній зоні 3 нарядом сил для вирішення цих же завдань у дальній зоні (у цінах 1996 року)

\begin{tabular}{|c|c|c|c|c|c|c|}
\hline \multirow{2}{*}{$\begin{array}{l}\text { Підкласи } \\
\text { катерів }\end{array}$} & \multicolumn{2}{|c|}{ Ближня зона } & \multirow{2}{*}{$\begin{array}{l}\text { Підкласи } \\
\text { кораблів } \\
\text { (катерів) }\end{array}$} & \multicolumn{2}{|c|}{ Дальня зона } & \multirow{2}{*}{$\begin{array}{l}\text { Економія коштів, } \\
\text { що передбачена, } \\
\text { млн дол. США }\end{array}$} \\
\hline & $\begin{array}{l}\text { Кількість } \\
\text { кораблів } \\
\text { (катерів) }\end{array}$ & $\begin{array}{l}\text { Вартість } \\
\text { наряду, млн } \\
\text { дол. США. }\end{array}$ & & $\begin{array}{l}\text { Кількість } \\
\text { кораблів } \\
\text { (катерів) }\end{array}$ & $\begin{array}{l}\text { Вартість } \\
\text { наряду, млн } \\
\text { дол. США }\end{array}$ & \\
\hline $\begin{array}{c}\text { Протичовновий корвет, } \\
\text { пр. } 1124\end{array}$ & 8 & 640 & Фрегат ПЧО & 8 & $2000-2400$ & $1360-1760$ \\
\hline $\begin{array}{c}\text { Ракетний катер } \\
\text { пр.1241.1 }\end{array}$ & 6 & $150-240$ & Фрегат КРЗ & 3 & 1000 & $850-760$ \\
\hline
\end{tabular}

Зрозуміло, забезпечити протиповітряну, протичовнову та протикорабельну оборону корабельних пошуково-ударних груп у районах пошуку підводних човнів у дальній зоні значно складніше. Ці види оборони можуть бути забезпечені винищувальною авіацією, переважно, з положення "чергування в повітрі", корабельними та авіаційними ударними групами. Це до $20 \%$ підвищує ризик втрат сил і засобів, що залучаються до бойових дій, i значно збільшуе витрати ресурсів.

Як показали розрахунки, ефективну протикорабельну оборону від дій корабельної ударної групи (КУГ) противника у складі фрегата та трьох корветів із керованою ракетною зброєю може забезпечити ударне угруповання бомбардувальної авіації Су-24М (до 30 літаків) у разі використання керованої ракетної зброї. Винищувальне прикриття корабельною ударною групою не враховувалось.

Аналогічне завдання без застосування бомбардувальної авіації 3 такою ж ефективністю (за умови прикриття КУГ чотирма винищувачами 3 положення “чергування в повітрі”) можуть виконати 12 ракетних катерів 3 протикорабельними ракетами (ПКР) “Терміт” (48 ракет “ТермітP”), 4 берегових ракетних дивізіони РК
"Утьос"

(32 ПКР "Прогрес"), 2 берегових ракетних дивізіони РК “Рубіж” (16 ПКР “Терміт-Р”).

В умовах обмеженості фінансових можливостей держави спільне вирішення завдань на морі дасть змогу відмовитись від потреби мати у складі ВМС значну кількість ракетних катерів i берегових ракетних протикорабельних комплексів, адже до складу угруповання для оборони морського узбережжя $\epsilon$ можливість виділити частини бомбардувальної та розвідувальної авіації Повітряних Сил. Однак, до того ж, необхідно виконати декілька важливих умов: бомбардувальну авіацію потрібно забезпечити необхідними протикорабельними зразками зброї; здійснити необхідну підготовку екіпажів для дій на морі.

3. Вартий уваги приклад вартісної оцінки варіантів дій для боротьби 3 морським тактичним десантом противника. Згідно 3 розробленою моделлю бойових дій для виконання завдання щодо розгрому десантного загону противника у складі 35 кораблів, катерів і транспортів та сил прикриття десанту (КУГ № 1: есмінеиь з керованою ракетною зброєю 1, корвет з керованою ракетною зброєю - 3; КУГ № 2: ракетних катерів - 4, торпедних катерів - 4) виділялось 25 бомбардувальників, 5 артилерійських, 4 ракетних катерів та 7 
винищувачів. Ці сили, згідно розрахунків, здатні тільки ускладнити дії десанту, у кращому випадку послабити десант. До того ж, зазначені сили під час боротьби з десантом i силами прикриття можуть зазнати до 25 30 \% втрат. Це близько 7-8 літаків, 2 катери.

$$
\text { Водночас завчасно поставлене }
$$
протидесантне мінне загородження (320 мін) на десантно-доступних напрямках 3 імовірністю підриву десантного корабля 0,75 може забезпечити також зрив висадки морського десанту противника. До того ж $є$ змога уникнути втрат авіації, надводних кораблів, які необхідно було б залучити для боротьби 3 десантом. Наряд сил для прикриття установлених мінних полів у декілька разів менший ніж наряд, що необхідний для розгрому десанту i сил прикриття. До його складу орієнтовно можуть бути включені 6-8 бомбардувальників, ударна група ракетних катерів, окремий береговий ракетний дивізіон ближньої дії. Вартість протидесантних мін, які потрібно виставити, становить близько десяти мільйонів доларів США (загальна вартість морської міни складає приблизно 30 тис. доларів США) [8]. Цей захід, крім збереження літаків i катерів, може дати ще певну економію інших ресурсів i матеріальних засобів.

4. Побудова протичовнової оборони та протипідводно-диверсійного забезпечення із застосуванням стаціонарних i позиційних гідроакустичних систем, як показали розрахунки, зменшить більш ніж у 1,5 рази потребу в маневрених протичовнових силах, які необхідно мати для виявлення підводних човнів у можливих районах їх дій 3 імовірністю 0,9. У кількісному виразі це 4-6 протичовнових кораблів (одна-дві корабельні пошуково-ударні групи).

Під час розгортання стаціонарних гідроакустичних систем виявлення підводних рухомих цілей корабельні та авіаційні пошуково-ударні групи застосовуються, переважно, 3 положення “чергування в базі”, “чергування на аеродромі”. Орієнтовна вартість розроблення, виробництва та монтажу стаціонарної гідроакустичної системи для з'ясування підводної обстановки становила на час розрахунків приблизно 200 млн доларів США. Дві корабельні пошуково-ударні групи протичовнових корветів (8 кораблів) мають вартість у 3-3,5 рази більшу (600-700 млн доларів США).

5. Для вирішення завдань протичовнової оборони у дальній зоні, 3 погляду вартості засобів

боротьби, найдоцільніше використовувати підводні човни. В умовах Чорного моря вони також є найефективнішим засобом для боротьби з надводними кораблями противника. Адже вони діють приховано. Прикриття районів дій своїх підводних човнів від протидії протичовнових кораблів та авіації противника може забезпечуватися береговими ракетними комплексами 3 дальністю дії до 300 км, ЗРК великої дальності, винищувальною та бомбардувальною авіацією.

До того ж вартість побудови протичовнового фрегата та дизельного підводного човна майже однакова (див. табл. 2).

На сьогодні та в близькій перспективі відсутність підводних човнів певною мірою може бути компенсована застосуванням мінної зброї.

У міру зростання фінансових можливостей держава в разі потреби зможе повернутися до розгляду питань щодо будівництва (придбання) підводних човнів і крупніших надводних кораблів для застосування в дальній зоні та навіть за межами Чорного моря [3].

6. Звичайно, не варто залишати увагою питання вартості строку служби, наприклад, корабля, катера, зразка зброї тощо. Вважається, що вартість строку служби включає: вартість досліджень та розроблення (етапи концепції, проєктування), вартість інвестицій (етап виробництва), вартість експлуатації та обслуговування (етап експлуатації та обслуговування), вартість виведення 3 експлуатації (етап виведення). Нижче в табл. 3 приведені типові коефіцієнти вартості етапів строку служби деяких систем озброєння (за даними Департаменту оборони США, кошторис систем озброєння: станом на 1999 рік). Як бачимо, вартість строку експлуатації надводного корабля складає приблизно $70 \%$ від вартості його життєвого циклу.

Під час оцінювання користі того чи іншого зразка ОВТ необхідно звертати увагу не тільки на вартість експлуатації та обслуговування (щорічні суми протягом всього строку), а й на тривалість строку експлуатації. Для прикладу наведемо окремі типи військової авіації США з тривалим строком експлуатації: винищувач F16 - 41 рік, стратегічний бомбардувальник В-52 - 89 років, військовотранспортний літак $\mathrm{C}-141$ - 41 рік, літак морської піхоти А-10 - 63 роки. 
Таблиця 3

\begin{tabular}{|c|c|c|c|}
\hline Тип системи & $\begin{array}{c}\text { Дослідження } \\
\text { та розроблення, \% }\end{array}$ & $\begin{array}{c}\text { Інвестиції, \% } \\
\text { Експлуатація, обслуговування } \\
\text { та виведення, \% }\end{array}$ \\
\hline $\begin{array}{c}\text { Літак з фіксованими } \\
\text { крилами }\end{array}$ & 20 & 39 & 41 \\
\hline Ракети & 27 & 33 & 39 \\
\hline Електронна техніка & 22 & 43 & 35 \\
\hline Кораблі $*$ & 1 & 31 & 58 \\
\hline Надводні кораблі & 9 & 37 & 70 \\
\hline Інформаційні системи & & 30 & 54 \\
\hline
\end{tabular}

Примітка*: Більшість витрат на проєктування кораблів включені в проєктування та виробництво першого корабля такого класу

7. На сьогодні доцільно розглядати удосконалення та розвиток мобілізаційної підготовки цивільного флоту як один 3 можливих і реальних варіантів посилення деякою мірою можливостей $\mathrm{BMC}$ за виконанням поставлених завдань. Практика застосування цивільних суден в умовах воєнних дій досить поширена та має свої корені й у минулому.

Так, під час проєктування цивільних суден за часів колишнього СРСР, у тактикотехнічних вимогах в обов'язковому порядку враховувались інтереси оборони. Урахування зазначеного фактора під час створення відповідних угруповань для ведення бойових дій на морі та у приморських районах дасть змогу концентрувати зусилля на створенні вкрай необхідних зразків озброєння та військової техніки.

Отже, прийняття воєнно-політичним керівництвом рішення щодо зосередження основних зусиль на завданні поразки противника в ближній зоні дає змогу розвивати, насамперед, сили прибережної зони. Різниця у вартості озброєння, яке може застосовуватись у ближній і дальній зонах може також дати економію значних коштів, які можуть бути використані для розвитку сил і засобів ППО, авіації, сил і засобів ВМС для дій у ближній зоні, засобів висвітлення повітряної, надводної, підводної обстановки та розвідки.

Наявність ефективної системи спостереження та розвідки дасть змогу використовувати авіацію, катери, протичовнові маневрені сили 3 положення “чергування на аеродромі”, “чергування в базі", що дає додаткову економію матеріально-технічних засобів і ресурсів.

Склад сил i засобів ВМС потрібно передусім поповнити ракетними та патрульними катерами, базовими та рейдовими тральщиками, мінними загороджувачами або десантними кораблями (типу пр. 775), що здатні встановлювати міни, військовими транспортами та десантними катерами прибережної зони плавання. Крім того, першочергова увага має бути приділена розвитку силам і засобам висвітлення підводної обстановки в морській зоні, засобам розвідки, РЕБ, оперативному маскуванню сил та об' єктів; силам і засобам ППО; тактичній та патрульній (протичовновій) авіації (літакам та вертольотам), безпілотним літальним i безекіпажним підводним апаратам різного призначення.

Висновки. Отже, для подальшої розбудови України як самостійної, незалежної, сильної держави особливу увагу слід зосередити на плануванні оборонних програм i складанні оборонних бюджетів та на вирішенні двоєдиного завдання із забезпечення обороноздатності держави та іï економічного зростання. На підставі наведеної інформації, можна сформулювати основні напрями зниження вартості вирішення основних завдань оборони морського узбережжя:

розроблення програм розвитку озброєння та військової техніки ВМС, зорієнтованих на дії в приморсько-прибережній зоні, забезпечує впровадження механізму, який унеможливлює вкладання фінансових ресурсів у проєкти (програми), що не відповідають оперативному призначенню ВMC;

для підтримки рішення щодо вибору та придбання того чи іншого зразка озброєння серед альтернативних для вирішення бойових завдань на морі необхідно також обраховувати та враховувати його цінність як відношення ефективності до вартості строку служби;

у процесі розроблення програм розвитку ЗС України, озброєння та військової техніки, ОПК в обов'язковому порядку мають враховуватися ресурсні можливості держави.

Подальші дослідження доцільно спрямувати на обгрунтування вимог до оперативних можливостей угруповань військ (сил), призначених для оборони держави 3 моря, на розроблення зразків озброєння, що відповідають оперативному призначенню ВМС, інших видів 3С України при їх залученні до бойових дій на морі, економічним та науково- 
технічним можливостям держави при забезпеченні заданої ефективності вирішення завдань на морі 3 мінімальними витратами фінансових та інших ресурсів.

\section{СПИСОК ВИКОРИСТАНОЇ ЛІТЕРАТУРИ}

1. Закон України "Про національну безпеку України 2018 року”. № 2469-VIII від 21. 06. 2018. Електронний pecypc https://законодавство.com/zakon-ukrajiny/zakonukrajini-pro-natsionalnu-bezpeku 358557.html.

2. Постанова Кабінету Міністрів України від 31 жовтня 2018 р. № 941 "Про затвердження Порядку проведення оборонного огляду Міністерством оборони". Урядовий кур'єр від 15.112018 - № 215.

3. В. Шрамович, П. Аксьонов “Москітний флот" чи фрегати: який флот будує Україна”, BBC News, Одеса-Київ, 28 грудня 2018.

4. Морська доктрина України на період до 2035 року (в редакції Постанови КМ № 1108 від 18.12.2018). Урядовий кур’єр від 30.12.2009 - № 244.
5. І. Назарчук. Військово-морські сили України: ексклюзивне інтерв'ю 3 командувачем ВМС Ігорем Воронченком. Політика, 29 червня 2018.

6. Волотівський П.Б. Вартісні аспекти створення угруповання сил (військ) для оборони приморськоприбережної зони України в Чорному морі. Матеріали міжнародного наукового форуму 20-21 червня 2018 року. Морська стратегія держави. Розвиток та реалізація морського потенціалу України. - К: НУОУ ім. Івана Черняховського, 2018. - 148 с.

7. Бегма В. М. Військово-технічна та обороннапромислова політикаУкраїни в сучасних умовах: аналіт. Доп./В. М. Бегма, О. О .Свергунов; упоряд. В. М. Маркелов, [за заг. ред. В. М. Бегми]. К. : НІСД, 2013 - 112 c.

8. А. Васильев "Минное оружие - самостоятельная система ведения морской войны”. Российское военное обозрение, апрель 2008 года, с. 51.

9. Воєнна доктрина України, затверджена Указом Президента України від 24 вересня 2015 року № 555/2015. Урядовий кур’єр від 26.9.202015 № 178 .

Стаття надійшла до редакційної колегії 07.08.2019

Волотовський П. Б., канд. воен. наук, ст. науч. сотрудник ${ }^{1}$;

Левчук Е. В., канд. экон. наук, доцент ${ }^{1}$;

Хвостиченко В. Н. ${ }^{2}$

1 - Центр военно-стратегических исследований Национального университета обороны Украины имени Ивана Черняховского, Киев;

2 - Центральный научно-исследовательский институт вооружения и военной техники, Киев

Военно-экономические аспекты боевых действий в прилегающих к черноморскому побережью Украины районах моря

Резюме. В статье рассматриваются возможные направления снижения стоимости решения задач обороны государства с морского направления при различных вариантах построения обороны морского побережья и способах применения войск (сил), которые отвечают критерию - высокая эффективность при приемлемых расходах и потерях

Ключевые слова: оборона морского побережья; экономическая эффективность как критерий решения боевых задач на море; ресурсные возможности государства; военно-экономические исследования; построение обороны государства с моря; решение задач боевых действий на море совместными усилиями видов вооруженных сил; ближняя зона оборони; дальняя зона обороны; стоимость эксплуатации образца вооружения и боевой техники.

P. Volotivsky, PhD (Military), senior researcher $^{1}$;

E. Levchuk, PhD (Economic), assistant professor ${ }^{1}$;

V. Khvostichenko ${ }^{2}$

${ }^{1}$ - Center for Military and Strategic Studies of the National Defence University of Ukraine named after Ivan Cherniakhovskyi, Kyiv;

${ }^{2}$ - Central Research Institute of Weapons and Military Equipment, Kyiv

Military-economic aspects of hostilities in the Black Sea coast of Ukraine

Resume. Possible ways of reducing the cost of solving the tasks of the state defense from the sea direction in different variants of construction of sea coast defense and methods of using forces (forces) corresponding to the criterion - high efficiency at acceptable costs and losses are considered in the article.

Keywords: defense of the sea coast; economic efficiency as a criterion for solving martial problems at sea; resource capabilities of the state; military-economic research; construction of the state defense from the sea; solving the tasks of military operations at sea by joint forces of the armed forces; the near-field defense zone; distant defense zone; cost exploitation of the model of armament and military equipment. 